\title{
Assessing the process of knowledge transfer - An empirical study
}

Article

Liyanage, C., Ballal, T. and Elhag, T. (2009) Assessing the process of knowledge transfer - An empirical study. Journal of Information and Knowledge Management, 8 (3). pp. 251-265.

ISSN 0219-6492 doi:

https://doi.org/10.1142/S0219649209002373 Available at https://centaur.reading.ac.uk/12271/

It is advisable to refer to the publisher's version if you intend to cite from the work. See Guidance on citing.

To link to this article DOI: http://dx.doi.org/10.1142/S0219649209002373

Publisher: World Scientific Publishing

All outputs in CentAUR are protected by Intellectual Property Rights law, including copyright law. Copyright and IPR is retained by the creators or other copyright holders. Terms and conditions for use of this material are defined in the End User Agreement.

\section{www.reading.ac.uk/centaur}

\section{CentAUR}

Central Archive at the University of Reading 
Reading's research outputs online 


\title{
ASSESSING THE PROCESS OF KNOWLEDGE TRANSFER - AN EMPIRICAL STUDY
}

\author{
Champika Liyanage'; Tabarak Ballal ${ }^{2}$; Taha Elhag ${ }^{3}$ \\ ${ }^{1}$ School of Built and Natural Environment, University of Central Lancashire, Preston, PRI 2HE, UK \\ ${ }^{2}$ School of Construction Management and Engineering, University of Reading, \\ Reading RG6 6AW, UK \\ ${ }^{3}$ School of Mechanical, Aerospace and Civil Engineering, University of Manchester, \\ Manchester M60 1QD, UK
}

\begin{abstract}
This paper investigates and evaluates the process of knowledge transfer in construction projects. Due to the highly competitive nature in business environments, knowledge transfer between organisations has become increasingly popular in recent years. However, although organisations can realise remarkable benefits by transferring knowledge from one unit to another, successful knowledge transfer can be difficult to achieve. The discussions presented in the paper are mainly based on findings of two case studies. The two cases were selected from Private Finance Initiative (PFI) projects in the UK. According to the case study findings, different stages of a knowledge transfer process can be overlapped, omitted, repeated as well as intermitted and then restarted. One of the significant findings of the case studies was the role of the 'knowledge mediator'. In selected case studies, there were external consultants and expert staff in the form of knowledge mediators. The importance of their roles was frequently highlighted by the interview participants. They were not only facilitating the close liaison between the knowledge source and the receiver, but their role was also strongly associated with practices of translation and interpretation. This combined role of mediator/translator, therefore, appears to be particularly significant for inter-organisational knowledge transfer in PFI projects.
\end{abstract}

Keywords: Communication, knowledge receiver, knowledge source, knowledge transfer, PFI projects. 


\section{INTRODUCTION}

The paper focuses on one of the major strands of the area of knowledge management, i.e. knowledge transfer (KT). As Abjanbekov and Padilla (2004) explicates, companies nowadays strive to establish and maintain competitive advantage, successful strategy, effective management and efficient use of resources. Therefore, it is argued that knowledge transfer can serve as a powerful catalyst for achieving these goals. However, the mechanisms by which knowledge is transferred need to be further understood and developed. These mechanisms can change due to several reasons such as the type of knowledge transferred, the type of entities (individuals, departments or organisations) involved and purpose of the knowledge transfer process. This paper aims to give an impetus to the current limited understanding of different mechanisms of knowledge transfer through an in-depth investigation of knowledge transfer processes and protocols using a case study approach. Despite the number of research carried out in the area of KM or indeed in the area of knowledge transfer, there is little literature that specifically indicates and acknowledges the significance of inter-organisational knowledge transfer in PFI environments.

The paper firstly introduces the concept of knowledge transfer and its significance in organisations together with a critique of the literature of the various knowledge transfer models and processes. It then proposes a comprehensive knowledge transfer model that is primarily based on the theories of translation and communication. Finally, the paper discusses different mechanisms of knowledge transfer within collaborative project environments focusing, in particular, on PFI projects.

\section{KNOWLEDGE TRANSFER - A THEORETICAL PERSPECTIVE}

\section{Operational definition}

Today, more than ever, knowledge matters. New terms and processes relating to management of knowledge are emerging everyday. We have the concept of knowledge workers. There is also the idea of a knowledge-based economy and knowledge-based industries in the business environment. Knowledge is, nowadays, regarded as the most critical resource of these economies, mainly due to the fear of 'knowledge loss'. Because knowledge-based resources are usually difficult to imitate and socially complex, the knowledge-based view of 
organisations posits that these knowledge assets may produce long-term sustainable competitive advantage (Alavi and Leidner, 2001). In recent years, due to the increasing competitiveness, construction organisations in the UK and other parts of the world have also moved towards these knowledge-driven economies.

Many existing literature in the field of knowledge management has sought to look into different aspects of organisation and management of knowledge in different conditions and in different contexts (e.g. organisational, individual, etc.). These different aspects branch into different areas of knowledge management. It ranges from knowledge creation (Nonaka, 1994), knowledge capture (Kamara et al, 2003; Shapiro, 1999), knowledge sharing (Dyer and Nobeoka, 2000; Hansen, 2002), knowledge transfer (Argote and Ingram, 2000; Gilbert and Cordey-Hayes, 1996; Tsai, 2001) to knowledge application (Holzner and Marx, 1979) and even to organisational learning and innovation (Lam, 1998; Vakola and Rezgui, 2000).

As mentioned in the previous section, the main focus of this paper is on one of these major strands of the area of knowledge management, i.e. knowledge transfer. Knowledge transfer is an area of knowledge management concerned with the movement of knowledge across the boundaries created by specialised knowledge domains (Carlile \& Rebentisch, 2003). It is the conveyance of knowledge from one place, person or ownership to another. Successful knowledge transfer means that transfer results in the receiving unit accumulating or assimilating new knowledge.

In today's highly competitive business environment, knowledge is viewed as a key strategic resource (Inkpen and Dinur, 1998; Nonaka, 1994; Simonin, 1999a \& 1999b), thus, the use and transfer of knowledge is increasingly seen as a basis for attaining competitive advantage. Knowledge transfer have been linked to improved manufacturing productivity, efficient use of resources, cost savings, time savings, expanding the remit of the business and developing sustainable competitive advantage.

Eliufoo (2005) claims that, although organisations can realise remarkable benefits by transferring knowledge from one unit to another, successful knowledge transfer can be difficult to achieve. There are several reasons for this, for example, individuals who do not understand why particular practices are effective may not be adept at communicating their knowledge to others, indeed organisations may not share information they possess with other 
competitors for various reasons. Furthermore, strong social identities and in-group favouritism may impede knowledge sharing across groups and divisions in organisations. Whilst these reasons hold for any organisational setup, they are particularly significant for those entities operating across multi-organisational boundaries such as construction organisations. It is argued that knowledge transfer can be even more difficult in such organisations due to their project-based orientation. Such orientation creates significant discontinuities in flows of personnel, materials and information (Bresnen et al, 2003) and hence knowledge (Eliufoo, 2005). Thus, there is a need to explore how such discontinuities could be mitigated. Knowledge transfer, therefore, could be seen as a method of mitigating 'knowledge loss' or 'knowledge discontinuity'.

Due to issues relating to knowledge loss and discontinuity, knowledge transfer is not easy to understand or practice, nor is there a proven best practice to transfer knowledge. Thus it is often difficult to provide a clear cut definition for knowledge transfer. This study, considering the knowledge sharing definition introduced by Christensen (2003) and acknowledging the inherent features that could be brought about by knowledge transfer application as explained by several other researchers (Argote and Ingram, 2000; Carlile and Rebentisch, 2003; Hoof and Ridder, 2004; Vito et al, 1999), has developed a definition for knowledge transfer as follows:

\footnotetext{
"Knowledge transfer is about identifying (accessible) knowledge that already exists and acquiring it and subsequently applying this knowledge to develop new ideas or enhance the existing ideas to make a process/action faster, better or safer than they would have otherwise been. So, basically knowledge transfer is not only about exploiting accessible resources, i.e. knowledge, but also about how to acquire and absorb it well to make things more efficient and effective in organisations."
}

\section{A proposed model for knowledge transfer}

The importance of knowledge transfer for successful organisational innovation is a recurring theme in the literature. Knowledge can only be valuable if it is appropriate, accurate and accessible to its users. Therefore, its effective transfer requires a framework of systems, methods and procedures, and an appropriate organisational culture (Karlsen \& Gottschalk, 2004; as cited in Cranefield and Yoong, 2005). With the many interpretations of the 
knowledge transfer process in effect, various knowledge transfer models have been introduced by many researchers. An example for some of these models is given in Table 1 .

--- Insert Table 1 here ---

According to Eliufoo (2005), some have simply viewed it as the knowledge of one actor being transferred to another, while some view it as a process performed in an organisation as part of the business process and usually supported by information technology based tools. For example, Vito et al. (1999) and Gilbert and Cordey-Hayes (1996) conceptualise the knowledge transfer process as encompassing two distinct dimensions, i.e. an information system and an interpretative system. Herein, information is the single component in the information system. The interpretative system, however, consists of five main components; namely: acquisition, communication, application, acceptance and assimilation. Gilbert and Cordey-Hayes (1996) stress that knowledge is transferred when it features in the core routines of the organisation and is reflected in the behaviour and practices of members, a stage identified as assimilation.

Major and Cordey-Hayes (2000) have also looked at several frameworks and models of knowledge transfer presented by different authors (e.g. Cooley, 1987; Cohen and Levinthal, 1990; Trott et al, 1995; Slaughter, 1995; Horton, 1997) in order to draw parallels between them. According to the nature and type of models they have reviewed, Major and CordeyHayes (2000) have categorised the models into two:

- node models; these describe nodes and discrete steps that are each gone through in a knowledge transfer process

- process models: these describe knowledge transfer by separate processes that are each undertaken.

Apart from aforementioned models, some researchers attempt to relate the process of knowledge transfer using different theories. Some of these are; translation theory (Holden and von Kortzfleisch, 2004; Jacobson et al, 2003; Abjanbekov and Padilla, 2004), agency 
theory (Arrow 1985; as cited in Boyce, 2001), intermediate modes and voice-exit and game theory (Boyce, 2001).

Most of the models, frameworks and theories discussed above, although contextually different, appear to have strong similarities. Fundamentally, issues concerning knowledge, collaboration and learning lie at the heart of most of these models and theoretical approaches. A close scrutiny would also suggests that the aforementioned theories and models have stemmed from the basic idea of collaboration and communication between the source (or sender) and receiver; an idea that has originally been introduced by Shannon and Weaver's mathematical approach to communication and information (1949; as cited in Carlile, 2004). This has then been further developed by Deutsch (1952) in his theory of communication. The practical strength of the original approach of communication and information is its mathematical capacity to adequately define the relations between source and receiver and their differences and dependencies. From the perspective of social sciences, two main points can be taken from this to simply explain the process of knowledge transfer. First is that a knowledge transfer process has two main components, i.e. the source or sender that shares the knowledge, and the receiver who acquires the knowledge. Secondly, knowledge transfer, although looks simple, is complex due to various prerequisites, factors and contextual issues surrounding the process.

The process of knowledge transfer is not, per se, a mere transfer of knowledge. As Seaton (2002) explicates, it requires an additional type of knowledge; 'the knowledge about how to transfer knowledge'. Seaton provides a simple example for this; instead of saying 'this is what I know', the process of knowledge transfer goes one step further to say 'this is what my knowledge means for you'. Thus, the purpose of knowledge transfer will be lost if knowledge is transferred from source to the receiver without contextualising the way it will be utilised by the latter. This process can be identified as knowledge transformation. Transformation denotes 'an organisation's capability to develop and refine the routines that facilitate combining existing knowledge and the newly acquired and assimilated knowledge' (Zahra and George, 2002). Transformation of knowledge is accomplished by simply adding or deleting knowledge. However, this can even involve interpreting the same knowledge in a different manner (i.e. 'translation'). As Cranefield and Yoong (2005) explains, 'as knowledge becomes more highly specialised, it develops its own terminologies... which typically reside with specialists... but (this), by definition, restricts the accessibility of the knowledge to the 
novice'. This suggests that there is a need for an act of translation during the process knowledge transfer.

According to some researchers, translation is a highly applicable analogy for exploring the nature of knowledge transfer (Holden and von Kortzfleisch, 2004). The theory of translation, which has hitherto been largely ignored by the knowledge management community, is significant for the process of knowledge transfer as it throws light on the knowledge transfer process from at least four advantageous perspectives (Holden and von Kortzfleisch, 2004):

- Translation as a networking activity: Translation is more than linguistic transcoding from one language to another. In the highly relevant words of Vermeer (1992; as cited in Holden and von Kortzfleisch, 2004), 'It has become common sense to integrate translation into a wider network of social relations'. This point applies to knowledge transfer because knowledge is not just transferred by means of transcoding from head to head, but also into the networks of knowledge receivers.

- Process and end-product quality: Translation theory is primarily concerned with two principal characteristics of translation, i.e. the quality of the final product and the actual translation process itself. This offers direct insights into aspects of knowledge transfer.

- Levels of accuracy: This can also be related to the knowledge transfer process. Whether someone is concerned with a translation or an act of corporate knowledge transfer, the vital challenge lies in being able to convey sufficient information so that receivers can make sense of it.

- Constraints on the production of good translations: The fourth perspective is an analogy which complements that ever growing area of the knowledge management literature which is concerned with constraints (or barriers) on smooth transfer of knowledge.

Based on the descriptive frameworks and models and related knowledge management literature and theories, a knowledge transfer model has been developed in this paper to yield a relatively complete and unified perspective for the process of knowledge transfer ${ }^{*}$. The

\footnotetext{
* The full ProFIK model and in-depth discussions relating to the model are given in Liyanage et al (2009).
} 
developed knowledge transfer model, which is named as the 'ProFIK model' (Procurement For Innovation and Knowledge), is depicted in Figure 1.

--- Insert Figure 1 here ---

The aforementioned model is primarily built upon two main components that are based on the theory of communication, i.e. the source and the receiver, (Deutsch, 1952; Shannon and Weaver, 1949 - as cited in Carlile, 2004). Apart from the theory of communication, theory of translation has also been taken into account when developing the model. The theory of translation explains the mechanism(s) as to how knowledge is transformed into a usable form.

Taking all these into consideration, the process of KT has been elaborated in the model in six main steps. They are, namely;

1. Awareness: identifying where the right knowledge is

2. Acquisition: acquire the knowledge provided that both receiver and source have the willingness and the ability and resources to do it.

3. Transformation: conversion of knowledge in order to make it 'useful' for the receiver where they can produce new knowledge or improve existing knowledge, skills or capabilities.

4. Association: recognising the potential benefit(s) of the knowledge by associating it with internal organisational needs and capabilities

5. Application: utilising the knowledge to improve organisations' capabilities

6. Knowledge externalisation/feedback: transfer the experiences or new knowledge created by the receiver to the source to make the process of KT reciprocal.

\section{EMPIRICAL STUDY AND ANALYSIS}

\section{Research design}


The paper is based on a research project titled 'Procurement for Innovation and Knowledge Transfer (ProFIK)'. As identified from the theoretical model presented in Figure 1, both the theory of communication and the theory of translation appear to be two different yet complementary theories for the area of knowledge transfer. The former explains the behavioural side of knowledge transfer, i.e. act of collaboration between the source and the receiver; whilst the latter sheds some lights on how to efficiently transform knowledge into a usable form. To identify the validity and reliability of the theoretical model it was needed to investigate knowledge transfer processes that occur in practice. An empirical research was, therefore, set to identify whether there is difference between the theoretical model and the actual processes of knowledge transfer and if so, why? The empirical study was also aimed at examining the following theoretical proposition:

- Effective knowledge transfer is an act of effective communication, collaboration and translation

The findings presented in this paper are mainly based on a case study methodology. The case study codes and the chosen knowledge transfer process in each case study are given in Table 2.

--- Insert Table 2 here---

The sample for the case studies was chosen from on-going Private Finance Initiative (PFI) projects. PFI was introduced by the Conservative Government (UK) in 1992; however its use only really took off after the election of the Labour Government in 1997. Although the role of PFI has expanded, the majority of public investment (over 85\% in 2003) is still carried out by traditional means of procurement. According to Public participation in Local Government Summary report (Birch, 2002), PFI involves extensive risk transfer to the private sector and accordingly greater cost certainty for the Government. In order to ensure this, the project is tightly specified in the contract, defining who bears which risk. Due to PFI's extent of use in the UK compared to other PPP (Public Private Partnership) models and their in-built interrelations, the term 'PPP/PFI' has become moreover a standardised way of introducing many public partnership projects. According to the statistics, there are currently about 800 PPP/PFI projects throughout the UK (Partnerships UK, 2007). 


\section{Details of the chosen knowledge transfer processes}

A number of different knowledge transfer processes have been observed in each of the case studies conducted. However, one knowledge transfer process was studied in-depth in each of the case studies in order to answer the research questions described in the previous section. The details of the chosen knowledge transfer processes are given as follows.

\section{Case Study 1 (CS1) - Unitised cladding system}

The selected knowledge transfer process of CS1 is relating to the Unitised Cladding System adopted in the project. Ensuring project cost certainty, minimising time spent on site and achieving high quality are the three main reasons for the contractor to adopt the unitised cladding system for the project. The cladding units were delivered and installed to the building, providing all appliances, surrounding finishes and supporting plumbing and electrics. Therefore, adopting this idea of 'unitised cladding' significantly reduced the labour hours and also took only a fraction of the time of a conventional construction method.

Although the concept of unitised cladding was not very much new to the construction industry, it was an innovative idea to the contractor. Since the contractor has had little or no knowledge at the beginning of the project, a knowledge transfer process has occurred during the project on gaining knowledge on the following list of things:

1. Identifying and selecting a suitable manufacturer to produce unitised claddings

2. Cladding fabrication and installation

3. Instigating health and safety procedures on handling the claddings

The protocols surrounding this process are discussed in a latter section of the paper.

\section{Case Study 2 (CS2) - Modular construction}

The selected knowledge transfer process of CS2 relates to a modular construction process adopted in the project. The modular units commissioned for the project were designed by a manufacturing company. This company and another manufacturer were then responsible for 
fabricating the modular units. Each fabricator has made approximately $50 \%$ of the total quantity, and has also taken responsibility for the delivery to site and erection of the modules and for the on-site works to install the linking corridors and internal finishes. Design of the modular bedrooms utilises pre-fabricated bathroom pods, manufactured by the two specialist fabricators. These were integrated into the bedroom modules during the assembly process off site. Other core components were sourced from more than one supplier to give security of supply.

Modular construction was chiefly used in CS2 to ensure certainty of completion of the project. The use of modules made this large scheme feasible by compressing the programme and simplifying the completion and handover of large numbers of room-units. Secondary development objectives included: avoidance of delay, cost certainty and achievement of highquality construction at a reasonable cost. According to the interviewees of CS2, adopting the concept of modular construction has given the project team a lot of advantages. As they put forth:

"One of the advantages of the modularised units is that because this isn't component architecture, builders don't have to wait for one piece being delivered and then the other piece. Basically, the builders can carry on working on site at any point on any one of the building."

- Architect (CS2)

"The beauty (of modular construction) is that this has a repetitive process, and therefore, it is like a factory production line. The timing of making it is lower. It is controlled quality."

- Project Manager (CS2)

Even though the modular construction was not a new concept to the contractors, this was the first time they adopted the concept on a larger scale. Due to its size and complexity and due to the fact that the special purpose vehicle (SPV) of the PFI is penalised for project delays, there was no room for any mistakes or faults by any of the project participants. Therefore, it was needed for the contractor to acquire expert knowledge from an external source(s). Thus, a knowledge transfer process has eventually taken place, starting from the point where they have decided to adopt the modular construction approach to the end where the modular units have successfully being 'plugged-in' to the project. This will be further explained in section 4 below. 
For each of the case studies outlined above, a number of professionals representing different organisations within the SPV have been interviewed with the aim of identifying how, why and to what extent knowledge transfer processes have occurred in these projects. Subsequent analysis of these interviews has revealed that knowledge transfer is indeed a recurrent process in PFI projects which occurs both formally and informally between and within different project teams.

As shown in Figure 1, theoretically, a knowledge transfer process consists of 6 main stages. The first is to identify the appropriate or valuable knowledge. This is named as 'knowledge awareness'. The next step then is to acquire the knowledge, provided that both receiver and source have the willingness and the ability to do it. This is so-called as knowledge acquisition. It refers to 'an organisation's capability to identify and acquire externally generated knowledge that is critical to its operations' (Zahra and George, 2002). Successful acquisition of knowledge, however, does not conclude the process of knowledge transfer. The acquired knowledge requires some sort of a conversion of knowledge in order to make it 'useful' for the receiver where they can produce new knowledge or improve existing knowledge, skills or capabilities. This again is a complicated process as it involves ensuring that the knowledge receiver have a knowledge-base heterogeneous enough to be able to take in new knowledge while still making sure existing knowledge is well leveraged and developed (Kalling, 2007). In the process model introduced, the process of converting knowledge into 'useful' knowledge at the receiver's end mainly involves two steps; first is 'knowledge transformation'. Transformation of knowledge can be accomplished by simply adding or deleting knowledge or by means of 'translation'. The second step of knowledge conversion involves relating the transformed knowledge to internal needs of the organisation. Trott et al (1995) name this step as 'knowledge association'. Knowledge association recognises the potential benefit of the knowledge by associating it with internal organisational needs and capabilities. Only then it becomes knowledge that is usable for the receiver. This 'useful' knowledge can then be applied to the organisation, i.e. knowledge application. After knowledge application, externalising knowledge in the form of a feedback loop is also essential to complete a successful process of knowledge transfer. 
Case study findings reveal that, although not as clear cut as the theoretical model, most of the stages described above appear to occur in practice during a knowledge transfer process. Figures 2 and 3 explain these stages in the selected two cases.

--- Insert Figure 2 here ---

---- Insert Figure 3 here ---

As illustrated in Figure 1, the ProFIK model, any knowledge transfer episode is triggered by a knowledge need (i.e. awareness of 'needed' knowledge) and culminates when the need is satisfied (i.e. successful application of the 'needed' knowledge) $)^{\dagger}$. This was evident from the two case studies as well (refer to Figures 2 and 3).

Knowing that knowledge exists and identifying where it exists is not sufficient for initiating knowledge transfer. It presupposes a great level of participation from the source and the receiver and also requires a strong association or relationship between them. A knowledge transfer process can often go wrong if the parties involved are unwilling to share knowledge due to issues of confidentiality, cultural difficulties and also due to fear of losing competitive edge. Even if the parties involved are willing to make an effort to share knowledge, according to Cranefield and Yoong (2005), the parties may be still be unable to transfer knowledge smoothly because of the inherent difficulties of the task(s). It is argued that knowledge transfer will be successful only if an organisation has not only the ability to acquire knowledge but also the ability to absorb it and then assimilate and apply ideas, knowledge devices and artefacts effectively. As many researchers suggest (Argote, 1999; Cohen and Levinthal, 1990; Rolland et al., 2003), absorptive capacity is one aspect that affects the success of a knowledge transfer process. Absorptive capacity is defined as the ability for a recipient of knowledge to recognise the importance and value of the external information, assimilate it, and apply it. The capacity depends on the firm's ability to recognise and link

\footnotetext{
${ }^{\dagger}$ As Holsapple and Joshi (2000) aver, the knowledge transfer episode can even end when the effort for finding the 'needed' knowledge is abandoned.
} 
new knowledge to its existing in-house expertise, and is a function of firm's level of prior related knowledge (Cohen and Levinthal, 1990).

It was apparent from the case study results that, in practice, organisations tend to apply different techniques to increase the absorptive capacity of a knowledge transfer process. In the chosen cases, the number of techniques used by CS1 was comparatively higher than CS2. On-the-job training is one of the main methods adopted by both cases to retain the knowledge acquired. In CS1 further techniques such as health and safety induction programmes followed by an aptitude tests and 'role plays by professional actors' were also used during the knowledge transfer process. From a knowledge transfer point of view, these are very much essential to increase the absorptive capacity of the knowledge receivers. For example, the role play helps the knowledge receivers to recognise and link the new knowledge to their tasks with little or no trouble. According to an interview participant, the aptitude test is also one of the very effective ways of checking whether the staff has 'absorbed' the required knowledge.

"The induction programme introduces what is supposed to be done, explain what the risks are and the end of that two hours the staff are given a test. It's different to other induction courses. You sit in an induction, they'd sign the book to say 'yes I've done the induction', but how do you know how they have understood the course. So, we undertake a small test at the end of the induction."

\section{- Project Coordinator (CS1)}

As some researchers (Dixon, 2000; Williams and Gibson, 1990) suggest, a knowledge transfer can occur in two ways: i.e. 'knowledge push' or 'knowledge pull' (or problem pull). As emphasised by Dixon (2000), in case of 'knowledge push', knowledge comes to the receiver because he wants as much (more or less unstructured) knowledge to come to him as possible, or knowledge is pulled as a consequence of a certain demand for knowledge. As Rogers (1995) explains, knowledge 'push' and 'pull' usually comes from the idea of whether need precedes knowledge or vice versa (Rogers, 1995). For example, if need precedes knowledge, it's 'knowledge push'. The concept of 'knowledge push' suggests that if one has sound scientific ideas, the technology (or knowledge) will transfer. However, in the selected two case studies, the said knowledge transfer processes has occurred due to the concept of 'knowledge pull'.

Of the case study findings, one clear deviation from the theoretical model was the absence of a 'knowledge association' stage. In both cases, once the 'needed' knowledge has been 
acquired by the knowledge champions and transferred (or translated) it to the main contractor and sub-contractors through several means (e.g. user manuals and guidelines, seminars, induction programmes, on-the-job training), it has being directly applied for product handling and installation. This may be due to the 'knowledge pull' concept of the chosen cases. 'Knowledge association' usually occurs when there is a necessity to match the acquired knowledge to organisational needs. As the authors perceive, knowledge association is, therefore, more significant for 'knowledge push' type of knowledge transfer processes than 'knowledge pull' types.

Even though the chosen knowledge transfer processes in selected case studies look very much alike in many instances (refer to Figures 2 and 3), the stage of knowledge externalisation clearly shows a difference between the two. Many can regard 'knowledge transfer' as a one-way-process where the receiver usually takes the bulk or all of the benefits. However, a success of knowledge transfer process should always take into account benefits gained at both ends (i.e. source and receiver). Thus, as the ProFIK model explains (refer to Figure 1), externalising knowledge is significant to transfer the experiences or new knowledge created by the receiver to the source (and other organisations involved). This can occur in the way of a feedback loop. According to the case study findings, in CS2, the source (manufacturer) and the receiver (main contractor) have carried out several on-going review meetings and knowledge exchange activities throughout the process of modularisation. It is also evident that, in CS2, the source has been extensively involved in the knowledge transfer process. This may be mainly due to the joint venture partnership the source and the receiver had as part of the PPP/PFI project arrangements. As the case study participants affirmed, this close association between the two organisations and the feedback mechanism has resulted in benefiting both the receiver and supplier in improving their operational performance. It has also resulted in creating long-term relationships between the two. Due to this, they are now in the process of extending their joint venture partnership in order to secure future projects for producing modularised units. This clearly a good case example that shows the rewards of having 'reciprocity' in a knowledge transfer exercise.

\section{KNOWLEDGE TRANSFER - COMMUNICATION, COLLABORATION AND TRANSLATION}


As repeatedly mentioned in previous sections, the ProFIK model of knowledge transfer is being built upon the theory of communication (Liyanage et al, 2009). Cranefield and Yoong (2005) states that the transparency of an organisation, i.e. the extent to which it is open to communication, is an important factor affecting the success of knowledge transfer. According to Nonaka (1994), transferring knowledge that has tacit components requires frequent and numerous interactions between the involved parties. Studies on communication and collaboration have suggested that the quality of the relationship is another important factor affecting knowledge transfer between a source and a receiver (Argote, 1999). Szulanski (1996) defined relationship quality as an emotionally non-laborious, close and good relationships between a source and a receiver. Thus, development of good relationships, communication and collaboration are likely to affect knowledge transfer (Baum and Ingram 1998). This is why the ProFIK model, from start to finish, is facilitated by constant interactions and communications. If not, the whole process collapses. From the case studies it was clear that this is extremely true in practice as well.

According to the case study findings, the project team always demonstrated a clear commitment to make the knowledge transfer process more efficient and effective. Along this process, some project teams/organisations had core roles; thus, had a direct involvement throughout, whilst others have supported the process of knowledge transfer in-directly (refer to Figures 2 and 3). All of them have used either formal or informal methods of communication to share and/or transfer knowledge. Most commonly used methods are: faceto-face discussions, frequent meetings, telephone, e-mail and web-based tools.

The main knowledge receiver in both cases was the main contractor. However, other project participants such as the sub-contractors, FM contractors, SPV and the architects were also benefited from the knowledge transfer exercise by gaining knowledge, at least, partially. The main knowledge source of both cases was the manufacturer of the unitised cladding or modular unit products. Interestingly, there were two parties, in both cases, who acted as the link between the source and the receiver (i.e. mediator) in the knowledge transfer process. They are namely, external consultants and knowledge champions.

Many organisations often do not know the ways of harnessing knowledge. Also, they may not know what they know and may also have weak systems to recognise where the 'right' 
knowledge is. Even if they did recognise the 'right' knowledge, they may not know the most appropriate way(s) of retrieving it. This is where getting the expertise from somebody else (an individual, team or organisation) become useful for a knowledge transfer process. As Figures 2 and 3 above reveal, both case studies have hired an external consultant who had experience and knowledge in the required areas, i.e. unitised cladding/modularisation. The external consultants were mainly chosen to find a suitable 'knowledge source' for the knowledge transfer process. In CS1, however, the external façade consultant was required to guide the main contractor throughout the rest of the knowledge transfer process as well. They also had to carry out a world-wide market survey to find the best manufacturer in unitised cladding. The manufacturer was eventually chosen from an Italian based company.

As identified in the previous section, in CS1, a clear feedback process was not present to pass on the final outcomes and experiences of the knowledge transfer process to the manufacturer (source). Besides, in comparison to CS2, the extent of the relationship between the source and the receiver was seemingly low. The physical distance between the two companies (Italy and UK) may be one of the main reasons for this. Physical distance herein refers to the difficulty, time requirement, and expense of communicating and getting together face-to-face (Cummings and Teng, 2003). According to Cummings and Teng, face-to-face meetings remain superior to other methods of technology-related communication. They further claim that tight interactions demand a close proximity. Therefore, studies investigating the impact of physical distance have found that the larger the distances between the parties, the slower and less the transfer of knowledge (Lester and McCabe, 1993). This is not totally true for CS1 as they have successfully completed the knowledge transfer process on-time with highquality project outputs.

Apart from external consultants, the two case studies also had knowledge champions to facilitate the process of knowledge transfer. In CS1, two site engineers were assigned the task of acquiring knowledge from the Italian company and subsequently transferring it to the main contractor and sub-contractors. They, therefore, had to make frequent visits to Italy to monitor the manufacturing process in order to study the product and to learn its handling and installation. Similarly, in CS2, two site operatives were chosen to monitor the manufacturing process of modular units (in two manufacturing sites) and understand the handling and installation of the finished product. 
The role of the external consultant and the knowledge champions was one of the key findings of the case studies. It was evident from the findings that they have played a pivotal role in the knowledge transfer process, performing a variety of activities at different stages. The importance of these roles was referred to frequently by the interview participants and was described by them as being essential to the success of knowledge transfer:

"You always have a tendered risk when you are going for a new product like this (modularised units). We had a quite a lot of problems with building regulations. It was very difficult, because people have never done it. Therefore, we had to employ an outside consultant."

- Project Manager (CS2)

\begin{abstract}
“.... we opened up the competition and competitive tender; so, we looked for companies that are equally as competent as the one we knew in London. For that we felt that it was important to network with people who have experiences in this kind of business. This is why we engaged a façade consultant.... We used his networks and experiences to find out who else might be equally in the frame for us to consider."

- Project Manager (CS1)
\end{abstract}

\begin{abstract}
"We had two people within our team, who are engineers by profession. They were working for the company since a long time, they have an awful lot of experience and also they were engaged in similar large projects in previous times. They actually go to Italy fairly regularly to monitor manufacture... they get familiarised with the product. Once they come here, they train the subcontractors. This is important to us because we can't just spend a lot of money on labour to bring installers all the way from Italy. That would also present us a risk factor. The two engineers follow the company procedures to train the installers."
\end{abstract}

- Project Coordinator (CS1)

In theory or in knowledge transfer terms, the roles of external consultant and knowledge champion are synonymous to the role of a translator/mediator. According to Cranefield and Yoong (2007), the role of translator/mediator demands both sound, in-depth, organisational knowledge, and also a range of skills for which there had been no recruitment exercise: strong interpersonal abilities and specialised (verbal, written and pictorial) skills in the communication and adaptation of new knowledge. These skills enable the mediators to convert new abstract and inaccessible knowledge; first into accessible, concrete examples within an appropriate disciplinary and organisational context, and second, into more individualised interpretations of the new knowledge, focusing at the job-specific level.

Cohen and Levinthal (1990) contend that an organisation's capacity to exploit external information effectively once inside the organisation depends heavily on prior experience with 
that knowledge. Crosson et al (1999) further assert that once knowledge enters an organisation, it must be transformed and institutionalised, enabling interpretation and shared meaning by members of the organisation. From the two case studies it was apparent that the external consultants and the knowledge champions have facilitated this process. More importantly, they have provided the link to bring the knowledge source and the receiver together throughout the knowledge transfer process (Refer to Figure 4). They have not only helped the receiving organisation to acquire the knowledge but have also helped them in successfully transforming and applying the knowledge where required.

--- Insert Figure 4 here ---

\section{SUMMARY AND CONCLUSIONS}

Due to the highly competitive nature in business environments, knowledge transfer between and within organisations has become increasingly popular in recent years. However, although organisations can realise remarkable benefits by transferring knowledge from one unit to another, successful knowledge transfer can be difficult to achieve. Since knowledge can only be valuable if it is appropriate, accurate and accessible to its users; its effective transfer requires a framework of systems, methods and procedures, and an appropriate organisational culture. With the many interpretations of the knowledge transfer process in effect, various knowledge transfer models have been introduced by many researchers. This paper presented a new model (i.e. ProFIK model) that portrays the key constituents of a knowledge transfer process. According to the proposed model, a knowledge transfer process usually consists of 6 stages, i.e. knowledge awareness, acquisition, translation, association, application and knowledge externalisation/feedback.

The case study analyses presented in the paper reveal some significant findings. The first is, although in theory, there are six separate but interlinked stages of knowledge transfer, in practice, the stages are not as clear cut. However, most of these stages can occur depending 
on the context and nature of the knowledge transfer process. Sometimes these stages can be overlapped, omitted, repeated as well as intermitted and then restarted.

The knowledge transfer processes of the two case studies are similar in context. This could be due to the fact that they are related to an introduction of a new product for the different projects and the context of the knowledge transfer process is 'knowledge pull'. This may mean that similar type of knowledge transfer processes can adopt a similar method and routine to transfer knowledge.

The proposed ProFIK model described above was mainly built upon two main components that are based on: (a) the theory of communication, (i.e. the source and the receiver of knowledge); and (b) the theory of translation, (i.e. the action of interpreting the transformed knowledge. Therefore, the case study results were finally used to test a theoretical proposition, i.e. 'effective knowledge transfer is an act of effective communication, collaboration and translation'.

According to the findings it was obvious that communication and collaboration is key to a knowledge transfer process. Interestingly, the roles of the external consultant and the knowledge champions (expert staff) have facilitated this process to a great extent. They have played a pivotal role in the knowledge transfer process, performing a variety of activities at different stages. In knowledge transfer terms, their role appears to be almost similar to the role of translator or mediator. The importance of these roles was referred to frequently by the interview participants. Their roles are highly specialised practices that are critical to knowledge transfer. This combined role of mediator/translator seems to be particularly significant in the context of inter-organisational knowledge transfer (e.g. for PFI projects) where it facilitates a close connection between the knowledge source and receiver. Therefore, it was evident that an effective knowledge transfer process is a combination of acts of communication, collaboration and translation. A combination of these appears to be offering much insights to the process of knowledge transfer mainly due to the following two obvious reasons:

- the process of knowledge transfer is an act of communication and collaboration: knowledge transfer involves either actively communicating to others what one knows, or actively consulting others in order to learn what they know. 
- the process of knowledge transfer is an act of translation: during the knowledge transfer process the transferred knowledge from one end could easily change its form, shape or appearance at the receiving end. Therefore, there is a need to interpret this transformed knowledge in a meaningful way, if it is to be utilised effectively by the receiver.

The research, on which this paper is based, plans to carry out more case studies in order to substantiate the findings presented above. This will further be strengthened by a questionnaire survey. The findings of the case studies and questionnaire survey will then be used to develop an effective framework for knowledge transfer in integrated procurement systems (particularly PPP/PFI projects). The framework will include, inter alia, a list of critical success factors that enable the process of knowledge transfer and a set of performance metrics that can be used to evaluate the success/failure of a knowledge transfer process.

\section{REFERENCES}

Abjanbekov A, and Padilla AEA. 2004. From Knowledge Transfer to Knowledge Translation: Case Study of a Telecom Consultancy. Linköping University: Department of Management and Economics.

Alavi M, and Leidner DE. 2001. Review: Knowledge management and knowledge management systems: Conceptual foundations and research issues. MIS Quarterly - Minneapolis. 25(1): pp. 107137.

Andersson U, Forsgren M, and Holm U. 2002. The strategic impact of external networks: subsidiary performance and competence development in the multinational corporation. Strategic Management Journal. 23: 979-996.

Argote L, and Ingram P. 2000. Knowledge transfer - A basis for competitive advantage in firms. Organisational Behaviour and Human Decision Processes. 82(1 - May issue): 150-169.

Argote L. 1999. Organisational learning: Creating, retaining and transferring knowledge. Norwell: Kluwer.

Baum JAC. and Ingram P. 1998. Survival-enhancing learning in the Manhattan hotel industry. 18981980. Management Science. 44: 996-1016.

Birch D. 2002. Public Participation in Local Government - A survey of local authorities. London. Local and Regional Government Research Unit. Office of the Deputy Prime Minister. 
Boyce GH. 2001. Co-operative structures in global business - Communicating, transferring knowledge and learning across the corporate frontier. London, Routledge: Taylor and Francis Group

Bresnen M. et al. 2003. Social practices and the management of knowledge in project environments. International Journal of Project Management. 21: 157 - 166.

Cantwell J. 1995. The globalisation of technology: what remains of the product cycle model? Cambridge Journal of Economics. 19: 155-174.

Carlile P. and Rebentisch E. 2003. Into the black box: The knowledge transformation cycle. Management Science. 49: 1180-1195.

Carlile PR. 2004. Transferring, Translating, and Transforming: An Integrative Framework for Managing Knowledge Across Boundaries. Organisation Science. 15(5): 555-568.

Christensen PH. 2003. Knowledge sharing - time sensitiveness and push-pull strategies in a non-hype organisation. EGOS Colloquium. Copenhagen Business School; Copenhagen.

Cohen WM. and Levinthal DA. 1990. Absorptive Capacity: A New Perspective on Learning and Innovation. Administrative Science Quarterly. 35(1): 128-152.

Cranefield J. 2007. Interorganisational knowledge transfer: the role of the gatekeeper . International Journal of Knowledge and Learning. 3(1): pp. 121-138.

Cranefield J. and Yoong P. 2005. Organisational factors affecting inter-organisational knowledge transfer in the New Zealand state sector - a case study. The Electronic Journal for Virtual Organisations and Networks. 7 (December Issue).

Crosson M, Lane H, and While R. 1999. An organisational learning framework from institution to institution. Academy of Management Review. 24(3): 522 - 538.

Cummings JL, and Teng BS. 2003. Transferring R\&D knowledge: the key factors affecting knowledge transfer success. Journal of Engineering and Technology Management. 20: 39-68.

Deutsch KW. 1952. On Communication Models in the Social Sciences. Public Opinion Quarterly. 16: page 356 .

Dixon N. 2000. Common knowledge - how companies thrive by sharing what they know. Harvard Business School Press; Boston. ISBN 0875849040. 
Dyer JH, and Nobeoka K. 2000. Creating and managing a high-performance knowledge-sharing network: the Toyota case. Strategic Management Journal. 21( 345-367).

Eliufoo HK. 2005. Knowledge creation and transfer in construction organisations in Tanzania. Building and Real Estate Economics. Stockholm. Royal Institute of Technology. Doctoral Thesis.

Gerybadze A, and Reger G. 1999. Globalisation of R\&D: recent changes in the management of innovation in transnational corporations. Research Policy. 28: 251-274.

Gilbert M, and Cordey-Hayes M. 1996. Understanding the process of knowledge transfer to achieve successful technological innovation. Technovation. 16(6): 301-312.

Gupta AK, Govindarajan V, and Malhotra A. 1999. Feedback-seeking behaviour within multinational corporations. Strategic Management Journal. 20(3): 205-222.

Hansen MT. 2002. Knowledge networks: explaining effective knowledge sharing in multiunit companies. Organisation Science. 13: 232-249.

Holden NJ, and Kortzfleisch HFO, 2004. Why cross-cultural knowledge transfer is a form of translation in more ways than you think. Knowledge and Process Management. 11(2): pp.127-136.

Holsapple CW. and Joshi KD. 2000. An investigation of factors that influence the management of knowledge in organisations. The Journal of Strategic Information Systems. 9(2-3): 235-261.

Holzner B. and Marx J. 1979. Knowledge application: the Knowledge system in society. Allyn and Bacon; Boston, MA.

Hooff B, and Ridder J. 2004. Knowledge sharing in context - the influence of organisational commitment, communication climate and CMC use on knowledge sharing. Journal of Knowledge Management. 8(6): 117-130.

Inkpen AC, and Dinur A. 1998. Knowledge Management Processes and International Joint Ventures. Organisation Science. 9(4).

Jacobson N, Butterill D, and Goering P. 2003. Development of a framework for knowledge translation: understanding user context. Journal of Health Services Research and Policy. 8(2): pp. 9499.

Kalling T. 2007. The lure of simplicity: learning perspectives on innovation. European Journal of Innovation Management. 10(1): pp. 65-89 
Kamara MJ. et al. 2003. Conceptual framework for live capture and reuse of project knowledge. Construction Informatics Digital library.

Kogut B, and Zander U. 1992. Knowledge of the Firm, Combinative Capabilities, and the Replication of Technology. Organisation Science Communication. 3: 383-397.

Kotabe M, Martin X, and Domoto H. 2003. Gaining from vertical partnerships: knowledge transfer, relationship duration and supplier performance improvement in the US and Japanese automotive industries. Strategic Management Journal. 24(4): 293 - 316

Lam A. 1998. Tacit Knowledge, Organisational Learning and Innovation: A Societal Perspective. DRUID Working Paper No. 98-22. Danish Research Unit for Industrial Dynamics.

Lester RK, and McCabe MJ. 1993. The Effect of Industrial Structure on Learning by Doing in Nuclear Power Plant Operation. Rand Journal of Economics. 24: 418-438.

Liyanage C. et al. 2009. Knowledge communication and translation - a knowledge transfer model. Journal of knowledge management. In press. 13 (1).

Mueller-Prothmann T, and Finke I. 2004. SELaKT - social network analysis as a method for expert localisation and sustainable knowledge transfer. In proceedings of I-Know '04 - 4th International Conference on Knowledge Management. Graz, Austria.

Nonaka I. 1994. A Dynamic Theory of Organisational Knowledge Creation. Organisation Science. 5(1): 14-24.

Partnerships-UK. 2007. Database. Retrieved 30th April 2007 from http://partnerships.org.uk/projectdatabase

Reagans R, and McEvily B. 2003. Network structure and knowledge transfer - the effects of cohesion and range.Columbia ideas@work. The Columbia Business School - Faculty and Research. Retrieved 10/01/2007. from

http://www2.gsb.columbia.edu/faculty/hhaveman/B9707/Reagans\%20\&\%20McEvily\%202003.pdf

Rogers EM. 1995. Diffusion of innovations. 4th edition. New York. Free Press.

Rolland N, Chauvel D, and Despres C. 2003. Knowledge Transfer and Organisational Learning in Strategic Alliances. In Research in Management Consulting: Enhancing Inter-firm Networks and Inter-organisational Strategies. 3: 93-116. 
Sakikibara M. 2002. Formation of R\&D consortia: industry and company effects. Strategic Management Journal. 23: 1033-1050.

Seaton RAF. 2002. Knowledge Transfer. Strategic tools to support adaptive, integrated water resource management under changing conditions at catchment scale - A co-evolutionary approach. Bedford. The AQUADAPT project.

Shapiro G. 1999. Inter-project knowledge capture and transfer: an overview of definitions. tools and practices. CoPS Innovation Centre Working Paper No 62. Brighton.

Simonin BL. 1999a. Transfer of marketing know-how in international strategic alliances: An empirical investigation of the role and antecedents of knowledge ambiguity. Journal of International Business Studies. 30(3): 263-291.

Simonin BL. 1999b. Ambiguity and the process of knowledge transfer in strategic alliances. Strategic Management Journal. 20: 595-623.

Stuart TE. and Podolny JM. 1996. Local search and the evolution of capabilities. Strategic Management Journal. 17: 21 - 38.

Sverlinger PO. 2000. Managing knowledge in professional service organisations. Department of Service Management. Gothenburg. Chalmers University of Technology. Doctoral thesis.

Szulanski G. 1996. Exploring internal stickiness - impediments to the transfer of best practice within the firm. Strategic Management Journal. 17(Winter special issue): 27-43.

Trott P, Cordey-Hayes M, and Seaton RAF. 1995. Inward technology transfer as an interactive process. Technovation. 15(1): pp. 25-43.

Tsai W. 2001. Knowledge transfer in intra-organisational networks: Effects of network position and absorptive capacity on business unit innovation and performance. Academy of Management Journal. 44(5): 996-1004.

Vakola M. and Rezgui Y. 2000. Organisational learning and innovation in the construction industry. The Learning Organisation. 7(4): 174-184

Vito A, Garavello AC, and Schiuma G. 1999. Knowledge transfer and inter-firm relationship in industrial districts: the role of the leader firm. Technovation. 19: 53- 63.

Williams F, and Gibson DV. 1990. Technology Transfer: Communications Perspective. SageThousand Oak: California. 
Zahra SA, and George G. 2002. Absorptive capacity - A review, reconceptualisation and extension. Academy of Management Review. 27(2): pp. 185-203. 
Table 1: Different knowledge transfer models and their sub-processes

\begin{tabular}{|c|c|c|c|c|c|c|}
\hline KT models & Sub-processes & & & & & \\
\hline $\begin{array}{l}\text { Argote } \\
(1999)\end{array}$ & $\begin{array}{l}\text { Sharing and } \\
\text { generating new } \\
\text { knowledge } \\
\end{array}$ & $\begin{array}{l}\text { Evaluating } \\
\text { knowledge }\end{array}$ & $\begin{array}{l}\text { Combining } \\
\text { knowledge }\end{array}$ & Application & & \\
\hline $\begin{array}{l}\text { Bartezzani et al., } \\
\text { (1997) }\end{array}$ & \begin{tabular}{|l} 
Abstraction and \\
generalisation
\end{tabular} & Embodiment & Dissemination & Application & & \\
\hline $\begin{array}{l}\text { Despres and } \\
\text { Chauvvel (1999) }\end{array}$ & Mapping & \begin{tabular}{|l|} 
Acquire, \\
Capture, Create
\end{tabular} & Package & Store & $\begin{array}{l}\text { Apply, Share, } \\
\text { Transfer }\end{array}$ & \begin{tabular}{|l} 
Re-use, \\
Innovate, \\
Evolve, \\
Transform
\end{tabular} \\
\hline Dixon (1992) & \begin{tabular}{|l|} 
Information \\
acquisition
\end{tabular} & \begin{tabular}{|l} 
Information \\
distribution
\end{tabular} & \begin{tabular}{|l|}
$\begin{array}{l}\text { Information } \\
\text { interpretation }\end{array}$ \\
\end{tabular} & Making meaning & $\begin{array}{l}\text { Organisational } \\
\text { memory }\end{array}$ & $\begin{array}{l}\text { Information } \\
\text { retrieval }\end{array}$ \\
\hline $\begin{array}{l}\text { Huber } \\
(1991)\end{array}$ & $\begin{array}{l}\text { Knowledge } \\
\text { acquisition }\end{array}$ & $\begin{array}{l}\text { Information } \\
\text { distribution }\end{array}$ & \begin{tabular}{|l|} 
Information \\
interpretation
\end{tabular} & $\begin{array}{l}\text { Organisational } \\
\text { memory }\end{array}$ & & \\
\hline Nevis et al, (1995) & $\begin{array}{l}\text { Knowledge } \\
\text { acquisition }\end{array}$ & \begin{tabular}{|l|}
$\begin{array}{l}\text { Knowledge } \\
\text { sharing }\end{array}$ \\
\end{tabular} & \begin{tabular}{|l|}
$\begin{array}{l}\text { Knowledge } \\
\text { utilisation }\end{array}$ \\
\end{tabular} & & & \\
\hline $\begin{array}{l}\text { Walsh, Ungson } \\
\text { (1991) }\end{array}$ & $\begin{array}{l}\text { Information } \\
\text { acquisition }\end{array}$ & $\begin{array}{l}\text { Information } \\
\text { storage }\end{array}$ & \begin{tabular}{|l|} 
Information \\
retrieval
\end{tabular} & & & \\
\hline $\begin{array}{l}\text { Wiig } \\
(1997 b)\end{array}$ & $\begin{array}{l}\text { Knowledge } \\
\text { creation }\end{array}$ & $\begin{array}{l}\text { Knowledge } \\
\text { capture }\end{array}$ & $\begin{array}{l}\text { Knowledge } \\
\text { transformation }\end{array}$ & Use & & \\
\hline $\begin{array}{l}\text { Gilbert and Cordey- } \\
\text { Hayes(1996); } \\
\text { Vito et al. } \\
(1999)\end{array}$ & $\begin{array}{l}\text { Knowledge } \\
\text { Acquisition }\end{array}$ & Communication & Application & Acceptance & Assimilation & \\
\hline Sverlinger (2000) & \begin{tabular}{|l} 
Knowledge and \\
information \\
acquisition
\end{tabular} & $\begin{array}{l}\text { Information } \\
\text { distribution }\end{array}$ & Making meaning & $\begin{array}{l}\text { Organisational } \\
\text { memory }\end{array}$ & $\begin{array}{l}\text { Retrieval of } \\
\text { information and } \\
\text { knowledge }\end{array}$ & \\
\hline
\end{tabular}

(Source: Sverlinger, 2000 and Eliufoo, 2005)

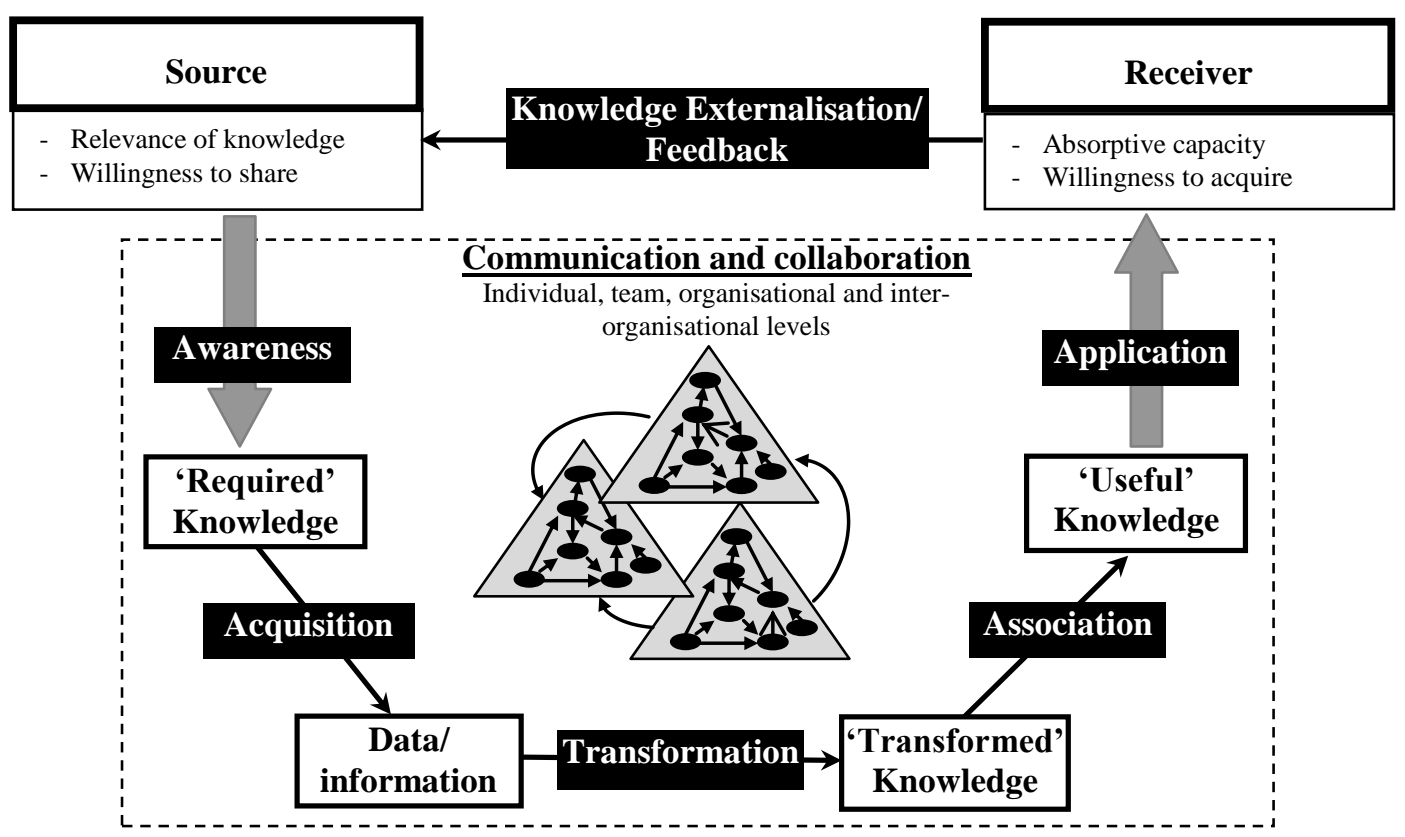

Figure 1: ProFIK - knowledge transfer model (adapted from Liyanage et al, 2009) 
Table 2: Case study details

\begin{tabular}{|l|l|l|}
\hline Case study no. & Case study code & $\begin{array}{l}\text { Chosen knowledge transfer process } \\
\text { in the case studies }\end{array}$ \\
\hline Case study 1 & CS1 & - Unitised cladding system \\
\hline Case study 2 & CS2 & - Modular construction \\
\hline
\end{tabular}




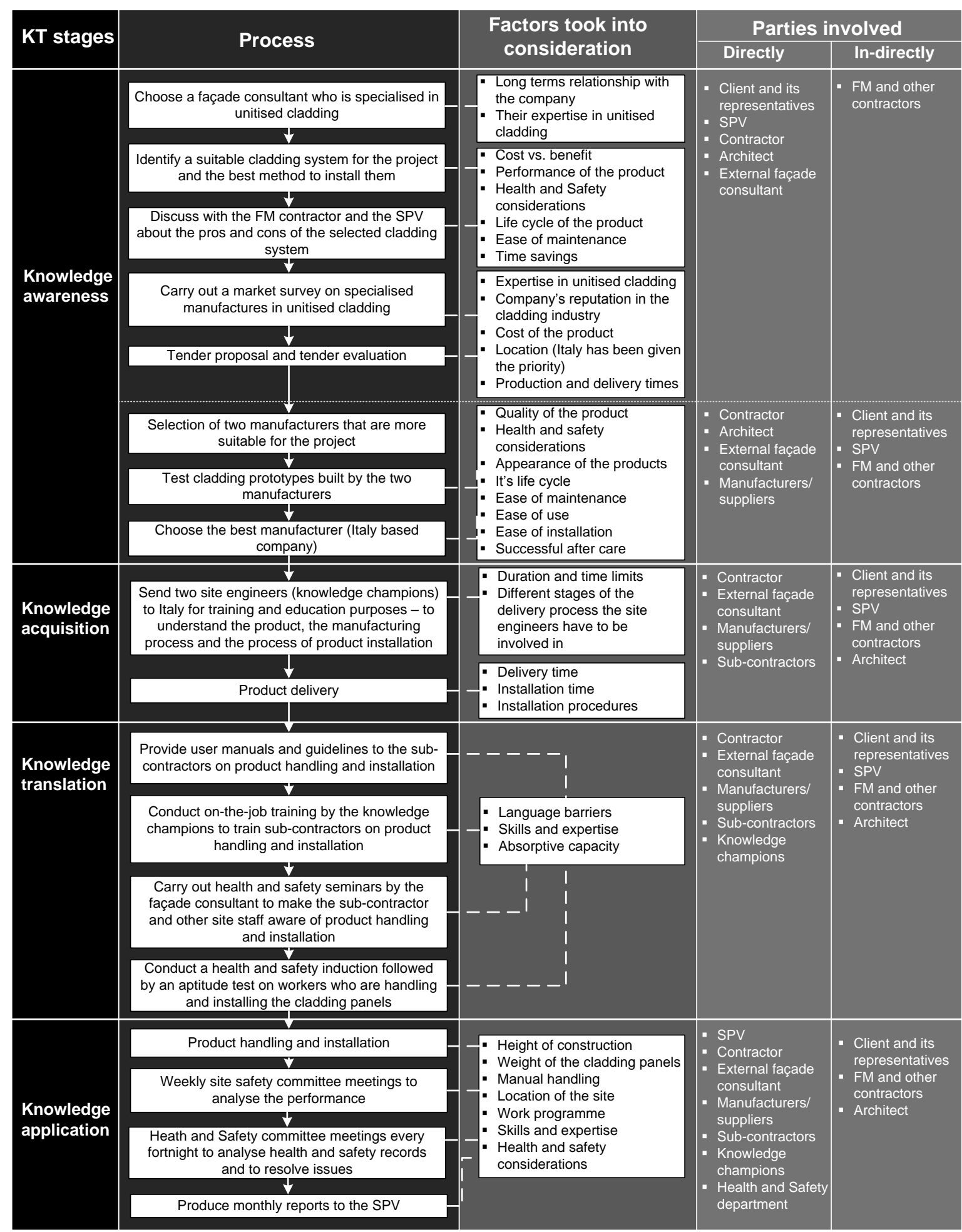

Figure 2: Knowledge transfer process - unitised cladding system (CS1) 


\begin{tabular}{|c|c|c|c|c|}
\hline \multirow{2}{*}{ KT stages } & \multirow{2}{*}{ Process } & \multirow{2}{*}{$\begin{array}{c}\text { Factors took into } \\
\text { consideration }\end{array}$} & \multicolumn{2}{|c|}{ Parties involved } \\
\hline & & & Directly & In-directly \\
\hline $\begin{array}{l}\text { Knowledge } \\
\text { awareness }\end{array}$ & $\begin{array}{l}\text { Compare the detail design against available cost } \\
\text { and time to identify suitable method of } \\
\text { construction for the project } \\
\text { Select modularisation process to produce over } \\
3000 \text { identical room-units } \\
\text { Discuss with the FM contractor and the SPV } \\
\text { about the pros and cons of the modularisation } \\
\text { process } \\
\text { Select a manufacturer who has past experiences } \\
\text { on producing modularised units }\end{array}$ & $\begin{array}{l}\text { - } \text { Work programme and time } \\
\text { savings } \\
\text { - } \text { Cost vs. benefit } \\
\text { - Health and Safety } \\
\text { considerations } \\
\text { - } \text { Life cycle of the product } \\
\text { - Ease of maintenance } \\
\text { - } \text { Long -term relationship with } \\
\text { the company } \\
\text { - Knowledge on the } \\
\text { modularisation process } \\
\text { - Long -term relationship with } \\
\text { the company } \\
\text { - Past experiences and } \\
\text { performance in } \\
\text { modularisation } \\
\text { - Financial stability } \\
\text { - Cost of the product } \\
\text { - Location of the manufacturing } \\
\text { site } \\
\text { - Long -term relationship with } \\
\text { the company } \\
\text { - Past experiences and } \\
\text { performance in } \\
\text { modularisation } \\
\text { - Cost of the product } \\
\text { - Location of the manufacturing } \\
\text { site }\end{array}$ & $\begin{array}{l}\text { - Client and its } \\
\text { representatives } \\
\text { - SPV } \\
\text { - Contractor } \\
\text { - Architect } \\
\text { - External } \\
\text { consultant } \\
\text { - FM contractor } \\
\text { - Manufacturers/ } \\
\text { suppliers } \\
\text { - Contractor } \\
\text { - Architect } \\
\text { - External } \\
\text { consultant } \\
\text { - Manufacturers/ } \\
\text { suppliers }\end{array}$ & $\begin{array}{l}\text { - Client and its } \\
\text { representatives } \\
\text { - SPV } \\
\text { - FM and other } \\
\text { contractors }\end{array}$ \\
\hline $\begin{array}{l}\text { Knowledge } \\
\text { acquisition }\end{array}$ & $\begin{array}{l}\text { Send two site operatives (knowledge champions) } \\
\text { to the two manufacturing sites - to monitor and } \\
\text { understand the product, the manufacturing } \\
\text { process and the process of product installation }\end{array}$ & $\begin{array}{l}\text { - Rate of production of } \\
\text { modularised units vs. the } \\
\text { work programme } \\
\text { - Quality of the product } \\
\text { - Cost of the product } \\
\text { - Work programme } \\
\text { - Product transportation } \\
\text { - Delivery time } \\
\text { - Installation time } \\
\text { - Installation procedures }\end{array}$ & $\begin{array}{l}\text { - Contractor } \\
\text { - Manufacturers/ } \\
\text { suppliers } \\
\text { - Sub-contractors }\end{array}$ & $\begin{array}{l}\text { - Client and its } \\
\text { representatives } \\
\text { - SPV } \\
\text { - FM and other } \\
\text { contractors } \\
\text { - Architect }\end{array}$ \\
\hline $\begin{array}{l}\text { Knowledge } \\
\text { translation }\end{array}$ & $\begin{array}{l}\text { Conduct on-the-job training by the knowledge } \\
\text { champions to train sub-contractors on product } \\
\text { handling, installation and health and safety } \\
\text { considerations }\end{array}$ & $\begin{array}{l}\text { - Language barriers } \\
\text { - Skills and expertise } \\
\text { - Absorptive capacity }\end{array}$ & $\begin{array}{l}\text { - } \text { Contractor } \\
\text { - Manufacturers/ } \\
\text { suppliers } \\
\text { - Sub-contractors } \\
\text { - Knowledge } \\
\text { champions } \\
\end{array}$ & $\begin{array}{l}\text { - Client and its } \\
\text { representatives } \\
\text { - SPV } \\
\text { - FM and other } \\
\text { contractors } \\
\text { - Architect } \\
\end{array}$ \\
\hline $\begin{array}{l}\text { Knowledge } \\
\text { application }\end{array}$ & 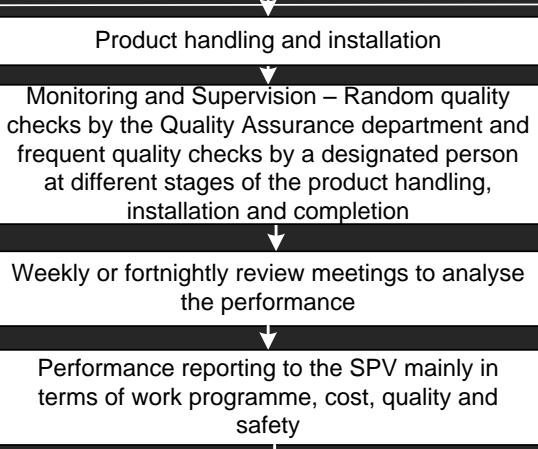 & $\begin{array}{l}\text { - Weight of the cladding panels } \\
\text { - Manual handling } \\
\text { - Location of the site } \\
\text { - Sork programme } \\
\text { - Healls and expertise } \\
\text { considerations }\end{array}$ & $\begin{array}{l}\text { - SPV } \\
\text { - Contractor } \\
\text { - Manufacturers/ } \\
\text { suppliers } \\
\text { - Sub-contractors } \\
\text { - Knowledge } \\
\text { champions } \\
\text { - Quality } \\
\text { Assurance } \\
\text { department } \\
\text { - Designated } \\
\text { person for quality } \\
\text { checks }\end{array}$ & $\begin{array}{l}\text { - Client and its } \\
\text { representatives } \\
\text { - FM and other } \\
\text { contractors } \\
\text { - Architect }\end{array}$ \\
\hline $\begin{array}{l}\text { Knowledge } \\
\text { externalisation }\end{array}$ & $\begin{array}{l}\text { Review meetings, on-going communication } \\
\text { between the source and the receiver }\end{array}$ & $\begin{array}{l}\text { - JV partnership } \\
\text { - Long-term collaboration to } \\
\text { secure new projects }\end{array}$ & $\begin{array}{l}\text { - } \text { Contractor } \\
\text { - Manufacturers/ } \\
\text { suppliers } \\
\text { - Knowledge } \\
\text { champions }\end{array}$ & \\
\hline
\end{tabular}

Figure 3: Knowledge transfer process - modularised units (CS2) 


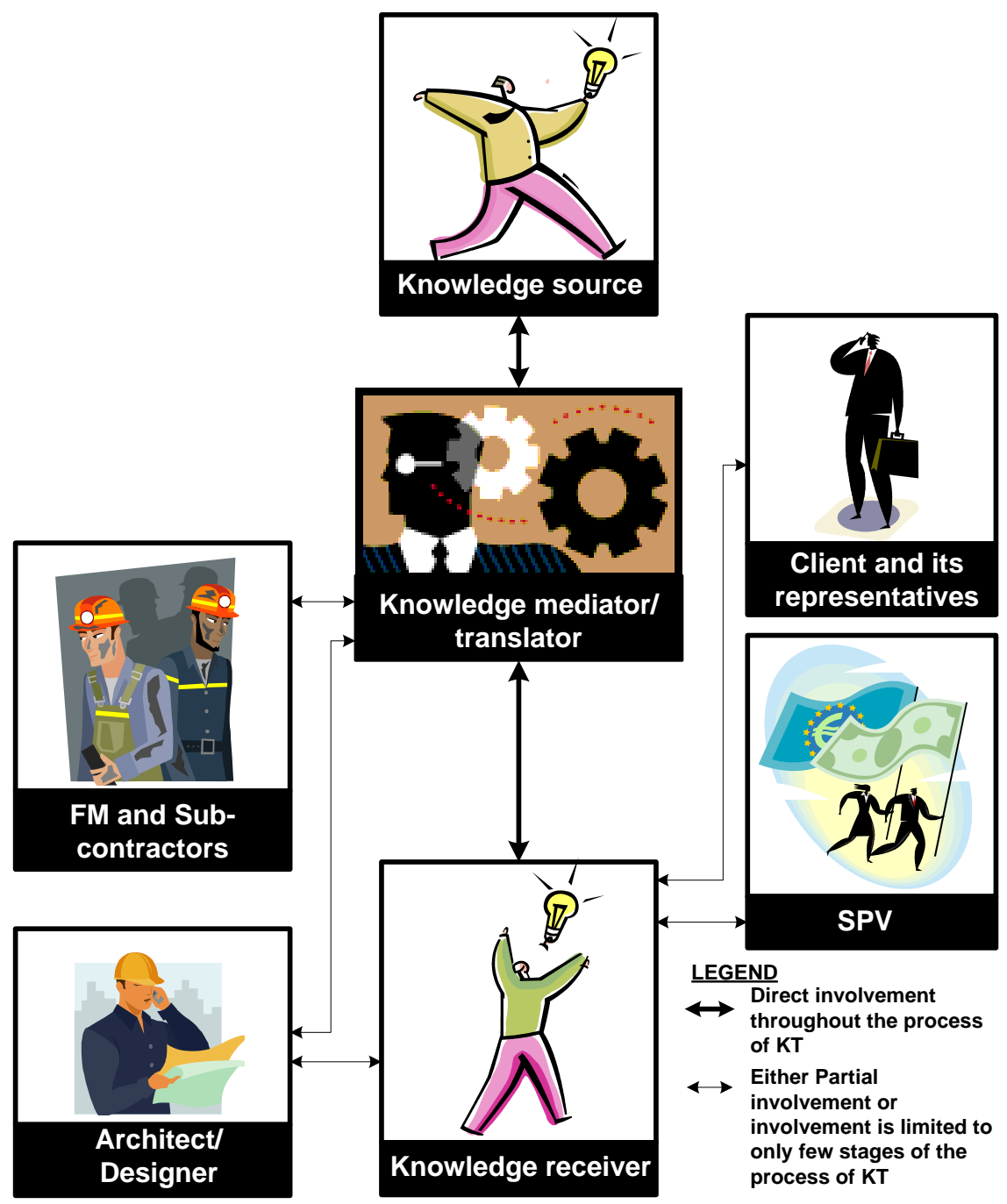

Figure 4: The role of the knowledge mediator/translator 